\title{
Application of Collaborative Management NEC and DAB to Improve Communication and Integration in Multi-Family Building Projects.
}

\author{
Mario Aragon Gonzales ${ }^{1}$, Jair Mamani Zevallos ${ }^{1}$, Jorge de la Torre ${ }^{2}$ \\ ${ }^{1}$ Universidad Peruana de Ciencias Aplicadas \\ San Isidro, Lima, Perú \\ U201420193@upc.edu.pe; u201422007@upc.edu.pe \\ ${ }^{2}$ Universidad Peruana de Ciencias Aplicadas \\ San Isidro, Lima, Perú \\ pccijdel@upc.edu.pe
}

\begin{abstract}
After the success of the Project for the Pan American Games in Peru, the mechanisms adopted by the organization to achieve the objectives proposed in the Project were made known to society. This research is based on adopting the NEC collaborative methodology mainly in the management of Stakeholders. For this reason, it is proposed to solve the problem of lack of communication and integration of Involved in Multifamily building projects, from the information collected about Collaborative Management NEC is made: (1) Analysis and evaluation of Involved. (2) Characteristics and strategies are proposed to manage Stakeholders. Likewise, (3) an analysis of the Dispute Resolution Board (DAB) is carried out and (4) the application of the ICE meetings tool is proposed to guarantee the correct flow of information in the project.
\end{abstract}

Keywords: New Engineering Contract (NEC), Collaborative Management, Stakeholders, Dispute adjudication Board (DAB), Integrated Concurrent Engineering (ICE) sessions, communication and integration, expert judgment, multi-family buildings.

\section{Introduction}

In any construction project there is big uncertainty to follow what is planned in the different stages of project, either due to poor planning, risks or other factors that generate changes in projects. Also, depending on the life cycle curve of a project while later changes are made, errors are detected or there are delays, is more expensive to correct that inconvenient for everything that has already done and would have to be changed. A clear example is that in 2018 the city of Lima concentrated about 340 multi-family buildings projects of which more than $60 \%$ had already passed the planning phase. However within this big group of companies there were still internal issues that affect the correct development of the project such as lack of communication, search for individual benefits and delays in delivery times [1].

In many countries of Europe and Asia, a collaborative methodology called NEC has been applied with optimal results. Likewise, in Peru it was applied for the first time in the execution of the sports infrastructure of Pan American Village, this methodology aims to propose a participatory management among Stakeholders to stimulate efficient management, have clarity in contracts and flexibility in their application. The article "Hong Kong's first public sector NEC contract: lessons learned" indicates that this methodology was implemented in order to avoid corruption, using a spirit of trust and mutual cooperation to achieve the common objectives of the project [2]. Likewise, the main contribution of the article "Briefing: Good faith obligations in NEC contracts" is that by applying the NEC methodology the same clauses mentioned by the previous author are indicated and structured so everyone involved in the project complies with this clauses for the welfare of the organization [3]. On the other hand, the article "Managing stakeholders through alliances: A case of megaproject in New Zealand" informs that there are many projects under collaborative modality in this country and this allowed Stakeholders to have a high level of integration. However, this information collected is little and that's why they evaluate the best practices: 1. Cultural care, 2. Communication and 3. Sensitivity. Finally the research shows a collaborative model that generates an effective participation of Stakeholders and it's called Alliance Model. [4]. In addition, the article "Kennedy town swimming pool - an NEC journey" indicates the way of performance in this project, this investigation focuses on the second stage (design and construction) the team did meetings with Stakeholders in order to solve problems in the execution 
of this project [5]. Previous studies agree that the application of collaborative management, such as the NEC methodology, generates greater value to the project. Simply, by being clearer, objective, seeking benefit to all parties, generate good communication and based on anticipation of possible risks. The contribution of the research is to make a collaborative management proposal, as is done in public projects worldwide involving all Stakeholders. In order to guarantee efficient communication and integration in multi-family building projects in the private sector.

\section{Methodology}

The method to be applied in the research is going to be the Collaborative Management NEC option F, which is bases on an efficient, flexible and clear direction. In addition, the PMBOK will be used, manly to develop a collaborative management plan for Stakeholders.

\subsection{Identification of Stakeholders in Building Projects According To NEC Collaborative Management.}

In the project Andres Avelino Caceres Complex, design and construction of venues required for the Pan American games were carried out under NEC methodology. So the analysis of Stakeholders will be an aid for the development of the investigation. In Table 1 the general information of Stakeholders is detailed, each letter means: I is Internal, E is External, $\mathrm{S}$ is Supporter, $\mathrm{N}$ is Neutral and $\mathrm{O}$ is Opponent.

Table 1: Characteristics and general information of the Stakeholders in the project analyzed.

\begin{tabular}{|c|c|c|c|c|}
\hline \multicolumn{2}{|c|}{ STAKEHOLDERS } & \multirow{2}{*}{$\begin{array}{r}\text { POSITION } \\
\text { Contractor (Peru) }\end{array}$} & \multirow{2}{*}{$\frac{\mathbf{I} / \mathbf{E}}{\mathrm{Int}}$} & \multirow{2}{*}{$\frac{\mathbf{S} / \mathbf{N} / \mathbf{O}}{\text { Sup }}$} \\
\hline $\begin{array}{l}\text { Contractor } \\
\text { (Client) }\end{array}$ & PEJP 2019 & & & \\
\hline \multirow{9}{*}{ Builder } & $\begin{array}{l}\text { SACYR } \\
\text { CONSTRUTION } \\
\text { S.A. }\end{array}$ & $\begin{array}{l}\text { Consortium } \\
\text { SACYR - SACEEM } \\
\text { (Peru - Spain) }\end{array}$ & \multirow{9}{*}{ Int } & \multirow{9}{*}{ Sup } \\
\hline & Paulo Almeida M & $\begin{array}{l}\text { Project Director } \\
\text { (Peru - Spain) }\end{array}$ & & \\
\hline & Jose Velarde Z. & $\begin{array}{l}\text { Commercial Manager } \\
\text { (Peru - Spain) }\end{array}$ & & \\
\hline & Julian Herrera A. & $\begin{array}{l}\text { Procurement Manager } \\
\text { (Peru-Spain) }\end{array}$ & & \\
\hline & $\begin{array}{l}\text { Antonio de Carvalho } \\
\text { S. }\end{array}$ & $\begin{array}{l}\text { Site Manager } \\
\text { (Peru - Spain) }\end{array}$ & & \\
\hline & Roger Lopez Z. & $\begin{array}{l}\text { Site Security Manager } \\
\text { (Peru - Spain) }\end{array}$ & & \\
\hline & Daniel Pérez G. & $\begin{array}{l}\text { Quality control Manager } \\
\text { (Peru - Spain) }\end{array}$ & & \\
\hline & Pedro Muñoz E. & $\begin{array}{l}\text { Design Manager } \\
\text { (Peru - Spain) }\end{array}$ & & \\
\hline & Pablo Eizmendi & $\begin{array}{l}\text { Programmer } \\
\text { (Peru-Spain) }\end{array}$ & & \\
\hline Supervision & - & $\begin{array}{l}\text { Supervision } \\
\text { (Peru-Spain) }\end{array}$ & Int & $\mathrm{Neu}$ \\
\hline
\end{tabular}

\begin{tabular}{|c|c|c|c|c|}
\hline \multicolumn{2}{|c|}{ STAKEHOLDERS } & \multirow{2}{*}{\begin{tabular}{l}
\multicolumn{1}{c}{ POSITION } \\
PMO \\
(U.K.)
\end{tabular}} & \multirow{2}{*}{$\begin{array}{c}\text { I/ } \\
\text { E } \\
\text { Int }\end{array}$} & \multirow{2}{*}{$\frac{\mathbf{S} / \mathbf{N} / \mathbf{O}}{\text { Sup }}$} \\
\hline $\begin{array}{l}\text { Project Management } \\
\text { Officer }\end{array}$ & $\mathrm{PMO}$ & & & \\
\hline $\begin{array}{l}\text { Dispute Adjudication } \\
\text { Board }\end{array}$ & $\begin{array}{l}\text { Members appointed } \\
\text { according to ICC }\end{array}$ & $\begin{array}{l}\text { DAB Members } \\
\text { (International) }\end{array}$ & Int & $\mathrm{Neu}$ \\
\hline Subcontractor & Various & Various (Peru) & Int & Sup \\
\hline Suppliers & Various & Various (Peru) & Ext & Sup \\
\hline Workers syndicate & Lima & $\begin{array}{l}\begin{array}{l}\text { Workers } \\
\text { (Peru) }\end{array} \\
\end{array}$ & Ext & Opp \\
\hline Neighbors & $\begin{array}{l}\text { Villa María del } \\
\text { Triunfo }\end{array}$ & $\begin{array}{l}\text { Neighborhood } \\
\text { (Peru) }\end{array}$ & Ext & Opp \\
\hline District Municipality & $\begin{array}{l}\text { Villa María del } \\
\text { Triunfo }\end{array}$ & $\begin{array}{l}\text { GDU - GTU } \\
\text { (Peru) }\end{array}$ & Ext & $\mathrm{Neu}$ \\
\hline $\begin{array}{l}\text { Metropolitan } \\
\text { Municipality } \\
\end{array}$ & Metropolitan Lima & $\begin{array}{l}\text { SDU }- \text { GTU } \\
(\text { Peru })\end{array}$ & Ext & Neu \\
\hline $\begin{array}{l}\text { Service } \quad \text { Operating } \\
\text { Entities }\end{array}$ & $\begin{array}{l}\text { Sedapal } \\
\text { Luz del Sur } \\
\text { Calidda, etc }\end{array}$ & $\begin{array}{l}\text { Workforce } \\
\text { (Peru) }\end{array}$ & Int & Sup \\
\hline Enviroment Ministry & $\begin{array}{l}\text { Fabiola } \\
\text { Muñoz }\end{array}$ & $\begin{array}{l}\text { Minister } \\
\text { (Peru) }\end{array}$ & Ext & $\mathrm{Neu}$ \\
\hline Final User & $\begin{array}{l}\text { Peruvian Institute of } \\
\text { Sports - Athlets }\end{array}$ & $\begin{array}{l}\text { User } \\
\text { (International) }\end{array}$ & Ext & $\mathrm{Neu}$ \\
\hline
\end{tabular}

2.2. Planning of Stakeholders Involvement in Building Projects According to NEC Collaborative Management.

To plan the involvement of Stakeholders, it's necessary to know more specific characteristics of each and evaluate their development respect to the project in order to propose management strategies. All Stakeholders from Table 1 are classified into groups according to matrixes. Fig 1. Shows all stakeholders analysed in the matrixes.

1. Power / Interest Matrix establishes strategies for relating with Stakeholders. In Fig. 2. The information is detailed.

2. Power / Influence Matrix is based on the level of authority and the ability to participate in the project. In Fig 3. The information is detailed.

3. Influence / Impact Matrix is based on participation and ability to make changes to the project. In Fig. 4. The information is detailed.

4. Cooperation / Threat Matrix is based on the potential to contribute to the project and the danger generated by those Involved in the project. In Fig. 5. The information is detailed.

5. Power / Dynamism Matrix is based on the power that Stakeholders possess and the flexibility of their position regarding the project. In Fig. 6. The information is detailed. 


\begin{tabular}{|l|l|}
\hline : Contractor (Client) & : Workers syndicate \\
: PMO & : Neighbors \\
: Supervision & $:$ District Municipality \\
: Contractor & $:$ Metropolitan Municipality \\
: DAB & $:$ Service operating entities \\
$:$ Subcontrator & $:$ Enviroment Ministry \\
: Suppliers & $:$ Final User \\
\hline
\end{tabular}

Fig 1: Legend of Stakeholders.

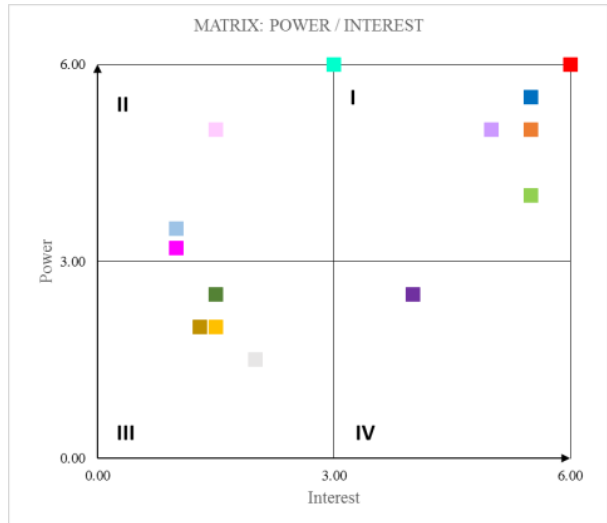

Fig 2: Matrix: Power - Interest.

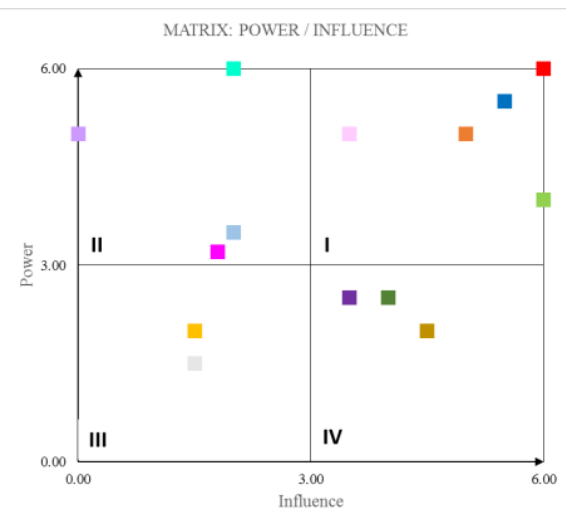

Fig 3: Matrix: Power - Influence.

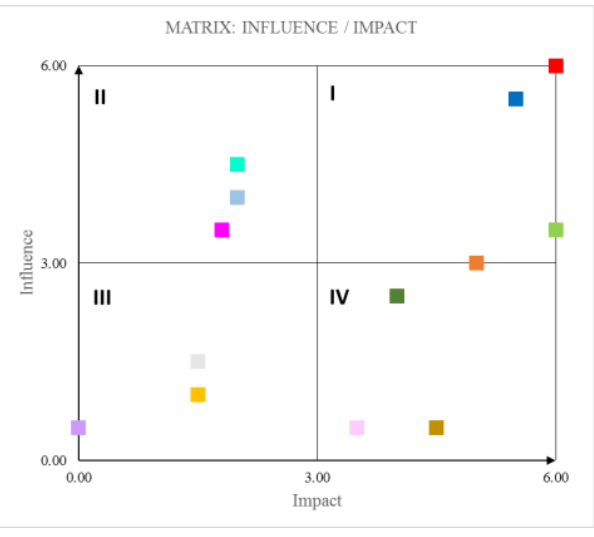

Fig 4: Matrix: Influence - Impact.

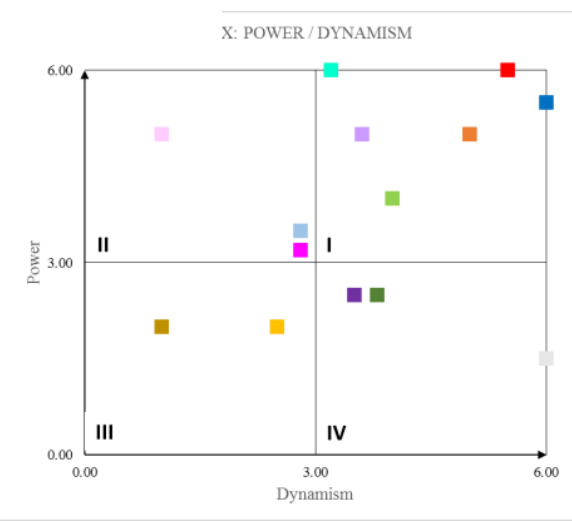

Fig 5: Matrix: Power - Dynamism.

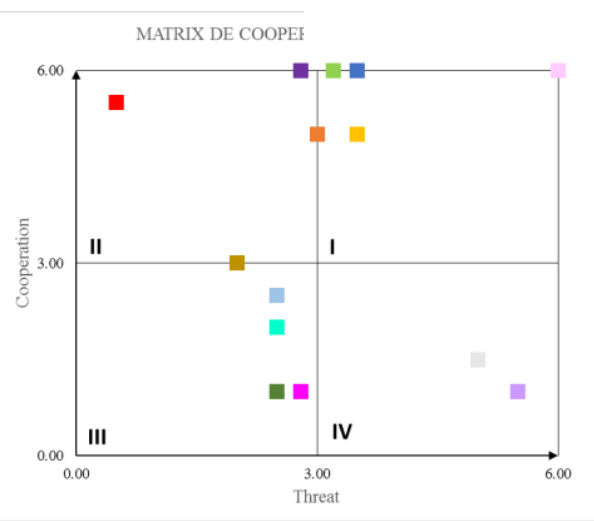

Fig 6: Matrix: Cooperation - Threat.

\subsection{Analysis of the Dispute Adjudication Board (DAB) in Building Projects according to NEC Collaborative management.}

Early dispute resolution is also a part of managing a project. All projects under NEC methodology executed worldwide use this tool. The use of DAB in early stages of the project can detect possible issues before they occur, make quick decisions and guarantee active participation in the execution, answer doubts and controversies as a prevention mechanism of arbitral tribunal. The team must be in constant communication with other Stakeholders, make site visits and convene constant meetings that guarantee communication and participation. The management by DAB Team in the project is shown in Fig 7. 


\section{Avoid \\ Prevent \\ Resolve}

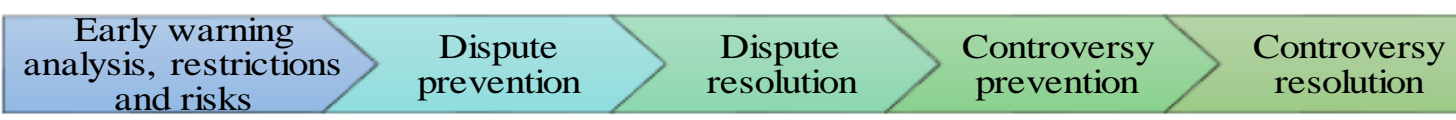

Fig 7: DAB Management. Source: Own Elaboration. Adapted from "Conference: The Dispute Resolution Board, an ideal mechanism to resolve public work controversies", by LLV Consultores, 2020. [6]

\section{Results}

\subsection{Characteristics of Stakeholders in Building Projects according to matrixes.}

Based on the data collected in the previous chapters, some characteristics and strategies are proposed to manage all Stakeholders. According to PMI, to realize a good management of Stakeholders it's necessary to communicate and work to satisfy the needs and expectations of each one of the parties, promote involvement according to the stage and function they have. All this with the objective to increase the chances of project success. These matrixes will help work team to manage Stakeholders under continuous improvement. Table 2. Details characteristics of Matrix: Power -Interest. Table 3. Details characteristics of Matrix: Power - Influence. Table 4 Details characteristics of Matrix: Influence - Impact. Table 5. Details characteristics of Matrix: Power - Dynamism. And Table 6. Details characteristics of Matrix: Cooperation - Threat.

Table 2: Characteristics of Matrix: Power - Interest.

Table 3: Characteristics of Matrix: Power - Influence.

\begin{tabular}{|c|l|}
\hline \multicolumn{2}{|c|}{ MATRIX POWER - INTEREST } \\
\hline Quadrant & \multicolumn{1}{c|}{ Characteristics and Strategies to Apply } \\
\hline I & $\begin{array}{l}\text { Manage carefully } \\
\text { Identify opportunities and threats regarding the project. }\end{array}$ \\
\hline II & $\begin{array}{l}\text { Their decisions may affect project continuity (stoppages, delays). } \\
\text { Guarantee project approval by this group. }\end{array}$ \\
\hline III & $\begin{array}{l}\text { Monitor their work according to the scope of the project, It's important } \\
\text { for the success of the project. }\end{array}$ \\
\hline IV & $\begin{array}{l}\text { Keep informed about the project. } \\
\text { Inspect the work done. }\end{array}$ \\
\hline
\end{tabular}

\begin{tabular}{|c|l|}
\hline \multicolumn{2}{|c|}{ MATRIX POWER - INFLUENCE } \\
\hline Quadrant & \multicolumn{1}{c|}{ Characteristics and Strategies to Apply } \\
\hline I & - Group that works constantly, high-level of authority and active involvement. \\
\hline II & $\begin{array}{l}\text { Inform them about the project constantly and pay attention to their activities. } \\
\text { Their decisions harm the development of the project. }\end{array}$ \\
\hline III & - Be informed with less emphasis than the other groups. \\
\hline IV & $\begin{array}{l}\text { - This group don't have high decision - making power or authority. } \\
\text { They get involved with the project and do important tasks to ensure the } \\
\text { project's completion. }\end{array}$ \\
\hline
\end{tabular}

Table 4: Characteristics of Matrix: Influence - Impact.

\begin{tabular}{|c|c|}
\hline \multicolumn{2}{|c|}{ MATRIX INFLUENCE - IMPACT } \\
\hline Quadrant & \multicolumn{1}{c|}{ Characteristics and Strategies to Apply } \\
\hline & $\begin{array}{l}\text { Group with the capacity to make changes in the planning and execution } \\
\text { of the project. }\end{array}$ \\
\hline II & $\begin{array}{l}\text { Ability to influence in changes of planning and execution. } \\
\text { They don't have active involvement in the project. }\end{array}$ \\
\hline III & $\begin{array}{l}\text { Irrelevant decision-making capacity. } \\
\text { - They must be informed about general aspects of the project. }\end{array}$ \\
\hline IV & $\begin{array}{l}\text { Don't have capacity or power to influence in project changes. } \\
\text { Important group to obtain good project results. }\end{array}$ \\
\hline
\end{tabular}

Table 5: Characteristics of Matrix: Power - Dynamism.

\begin{tabular}{|c|l|}
\hline \multicolumn{2}{|c|}{ MATRIX POWER - DYNAMISM } \\
\hline Quadrant & \multicolumn{1}{c|}{ Characteristics and Strategies to Apply } \\
\hline I & $\begin{array}{l}\text { High level of authority. } \\
\text { Predictable, their decisions can be anticipated. }\end{array}$ \\
\hline II & $\begin{array}{l}\text { They are the most dangerous and represent great opportunities for } \\
\text { improvement if we carry out a good stakeholder management. }\end{array}$ \\
\hline III & $\begin{array}{l}\text { Unpredictable but manageable. } \\
\text { Appropriate management generates simple control. }\end{array}$ \\
\hline IV & This group generate few problems. \\
Efficient management generates very low severity.
\end{tabular}

Table 6: Characteristics of Matrix: Cooperation - Threat.

\begin{tabular}{|c|l|}
\hline \multicolumn{2}{|c|}{ MATRIX COOPERATION - THREAT } \\
\hline Quadrant & \multicolumn{1}{c|}{ Characteristics and Strategies to Apply } \\
\hline I & $\begin{array}{l}\text { - Mixed Interest group. } \\
\text { Contribute with the necessary to ensure a good relationship. }\end{array}$ \\
\hline II & $\begin{array}{l}\text { Support Interest group. } \\
\text { - Involve within the project and maintain a good relationship to guarantee a good performance. }\end{array}$ \\
\hline III & $\begin{array}{l}\text { - Marginal Interest Group. } \\
\text { - These Stakeholders must be controlled and guarantee the accomplishment of their functions. }\end{array}$ \\
\hline IV & $\begin{array}{l}\text { No-Support Interest Group manage them defensively. } \\
\text { - Considered a threat to proper execution of the project. }\end{array}$ \\
\hline
\end{tabular}




\subsection{Application of ICE Sessions.}

ICE Sessions are meeting where stakeholders discuss and agree on efficient solutions for any problem that is detected detected in advance. These sessions guarantee the correct flow of information, as well as important actions to do and evaluate restrictions correctly. Based on this, decisions will be made jointly considering opinions of Stakeholders in this process. Benefits to apply ICE Sessions are detailed in Table 7.

Table 7: Benefits of the ICE Sessions application.

\begin{tabular}{|l|l|l|}
\hline \multicolumn{1}{|c|}{ TIME } & \multicolumn{1}{|c|}{ QUALITY } & \multicolumn{1}{c|}{ INTEGRATION } \\
\hline Reduce redesign & Optimized solutions & $\begin{array}{l}\text { More effective communication and interaction of the } \\
\text { Stakeholders }\end{array}$ \\
\hline Less time in making decisions & Major innovation & $\begin{array}{l}\text { More sense of belonging and correct performance of } \\
\text { activities in the project. }\end{array}$ \\
\hline Faster and more efficient design & Quality improvement of the final product & More creativity to solve problems \\
\hline $\begin{array}{l}\text { Accomplish deadlines in less time due to } \\
\text { teams integration }\end{array}$ & $\begin{array}{l}\text { Higher productivity due to efficient and optimal use } \\
\text { of human resources }\end{array}$ & Prioritize tasks and problems to solve \\
\hline $\begin{array}{l}\text { Shorter meeting and proper follow-up of } \\
\text { the agenda }\end{array}$ & Efficient and transparent management & Different perspective for solving problems \\
\hline
\end{tabular}

Source: Own Elaboration. Adapted from «Everything about ICE meetings in VDC method» by BIM CORNER, 2020 [7].

To guarantee that ICE sessions will be efficient and exploited by Stakeholders, each project must analyse and share the variables to be discussed in the meetings, as well as assign responsible who are in charge of planning the session and identifying the required objectives or topics to be discussed. Therefore, a procedure is proposed for the application of ICE sessions. Table 8 details the process to follow.

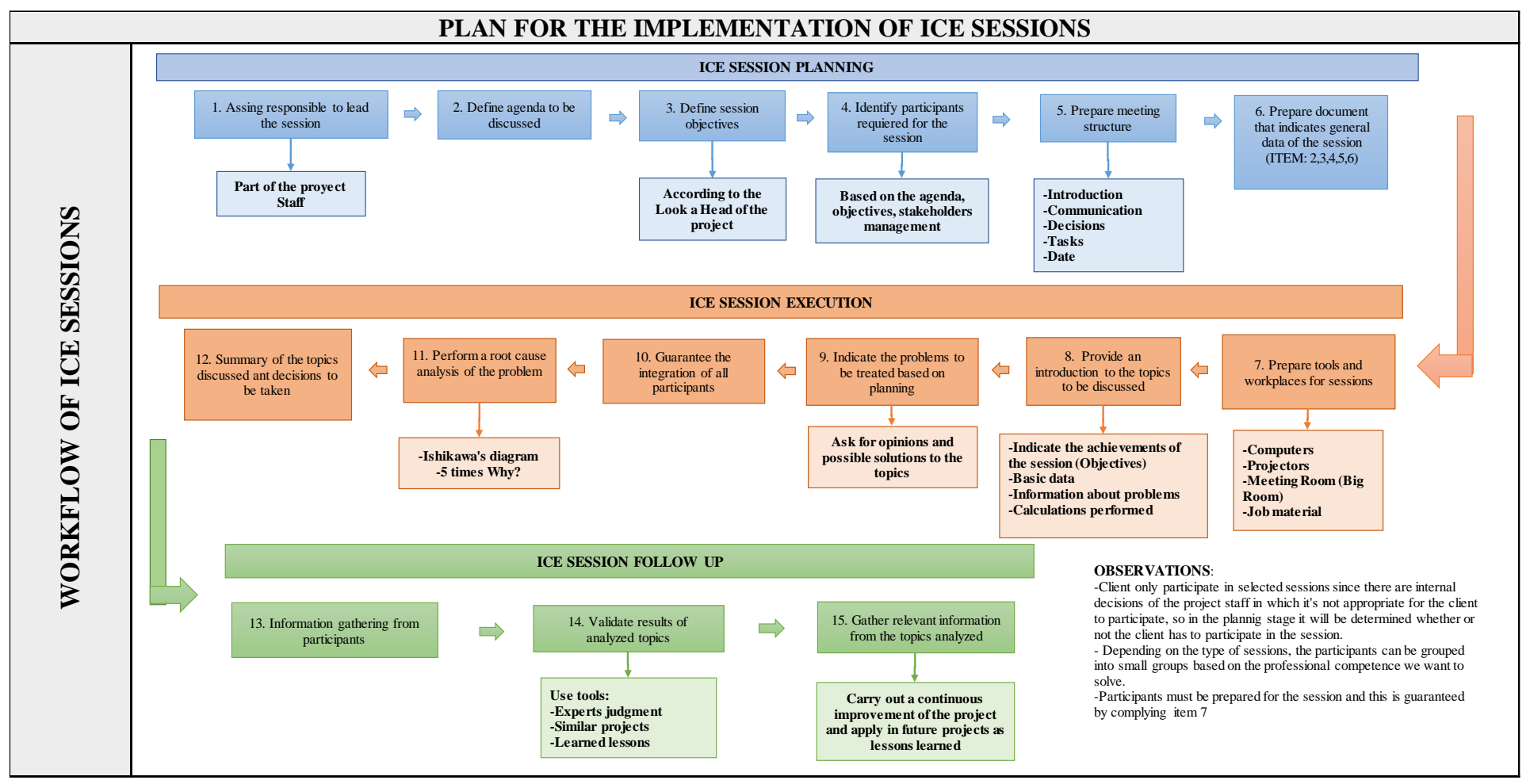

Fig 8. Workflow for the Implementation of ICE sessions. 


\subsection{Adaptation of the Dispute Adjudication Board (DAB) in Multi-family buildings projects according to the Collaborative management NEC.}

To Adapt the DAB in projects of Multifamily Buildings, a flow chart was made that represents the procedure that is carried out in the decision-making of DAB. Fig 8. Shows the procedure to follow. Likewise, as indicated in the methodology, DAB team will be in constant integration with those stakeholders in the Project, so it's necessary that there be a report format that they make on each occasion that is requested, either due to a controversy or suggestion of any topic.

The format that the DAB must perform to answer any doubts has some important points that are: Disputed issues, details about the problems and request to start the dispute. DAB's Procedure, describe DAB's opinion with a preliminary program or the dispute period, list of documents received, detail preliminary meetings and possible date to visit building site. Preliminary Issues, brief description of the issues in dispute, position of each party and the conclusion of DAB. Issues, Brief description of preliminary issues, DAB's recommendation including reasons. Summary table showing claim, defendant's assessment and DAB's final decision.

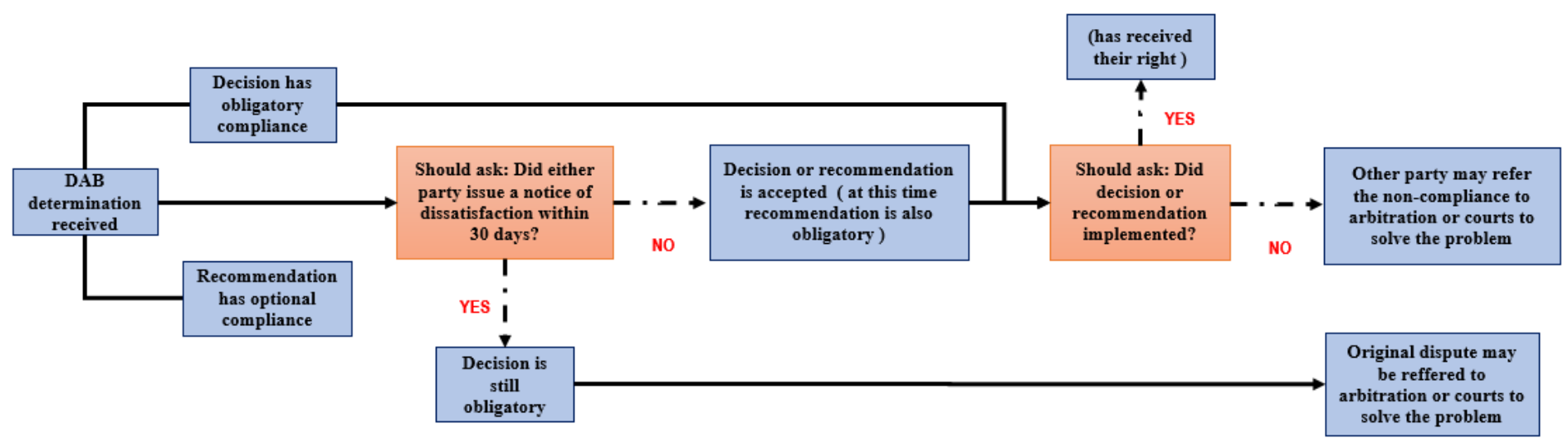

Fig 9: DAB decision procedure. Own Elaboration Adapted from «Implementing and enforcing a dispute board's decision » by ICE, $2016[8]$

\section{Validation}

\subsection{Experts Judgment}

To apply this tool a survey was carried out on 19 Engineers and Architects related to Pan American Games Special Legacy Project. All these professionals are construction projects management experts in the best companies in Peru and fully related to collaborative management NEC. Names such as Marco Agama, Cesar Rojas, PEJP Project Managers; also Brenda Martinez, architect of the PEJP project were participants in the survey. First question to validate the research was if there is a benefit to use a Collaborative management compared to Traditional methodology, the answers are shown in Fig 9. A key question is about Stakeholders identification systems, the answers are shown in Fig 10. A Pareto diagram is shown in Fig 11. About the main problems of Stakeholders non-management. Likewise, Fig 12. Shows main problems with stakeholders in building projects. About DAB, the question in Fig 13. Indicates the importance of having a conflict resolution system in this kind of projects. Finally, two questions are included, one about the characteristics of traditional projects and how team project focus on ensure an adequate management, in Fig 14. Shows the results. The last question is about the benefits of using a Collaborative Management compared to traditional, all answers are shown in Table 10. 


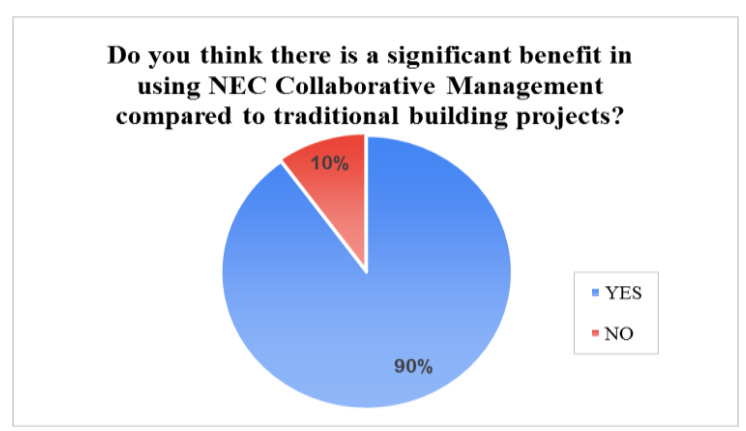

Fig 10: Circular Diagram based on the benefits applying Collaborative Management.

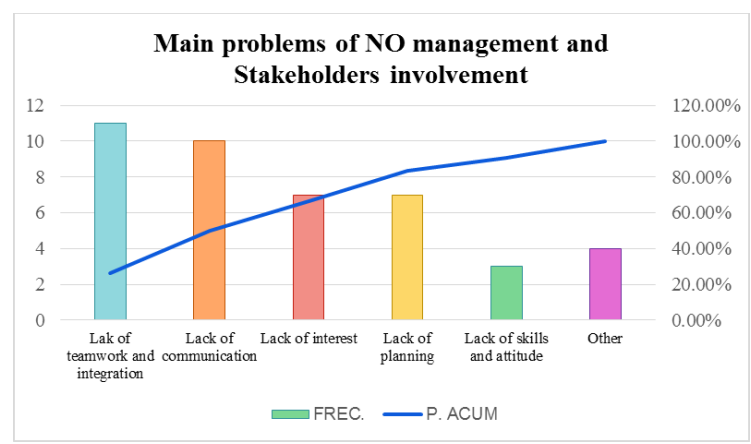

Fig 12: Pareto Diagram based on the main problems of lack Stakeholders management.

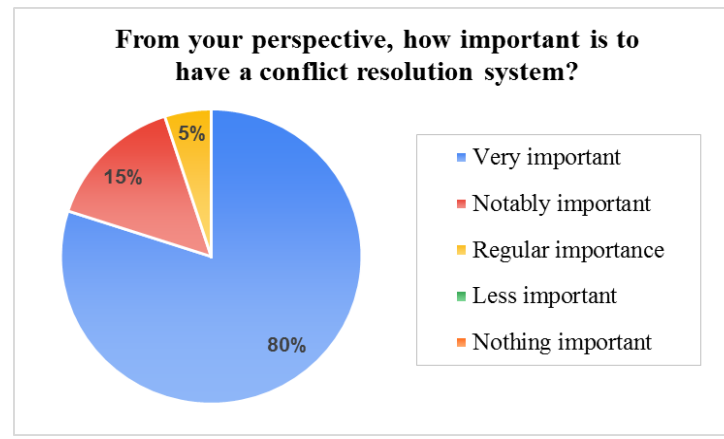

Fig 14: Circular Diagram about the importance of having $\mathrm{DAB}$ in projects.

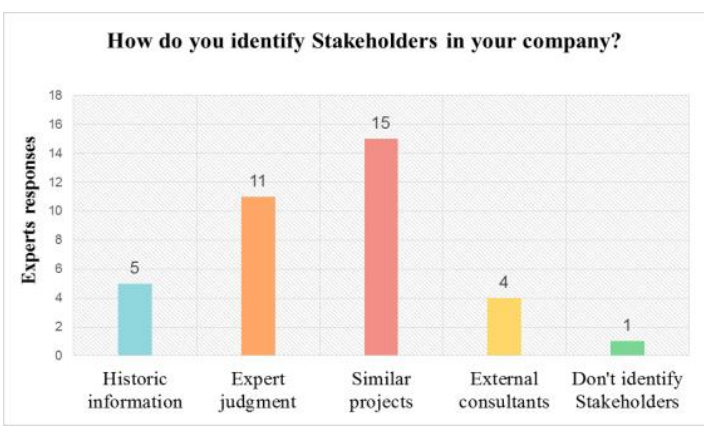

Fig 11: Bar Diagram based on Stakeholders identification in experts projects.

What are the most common problems you have with stakeholders?

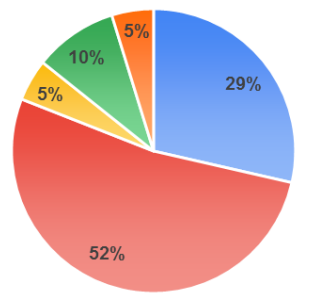

- Deficient information or documentation

- Search for individual and not collective benefit

- Delay in aproval permits and licenses

- Lack of qualified workers

- Errors and incompatibilities

Fig 13: Circular Diagram based on the most common problems with Stakeholders.

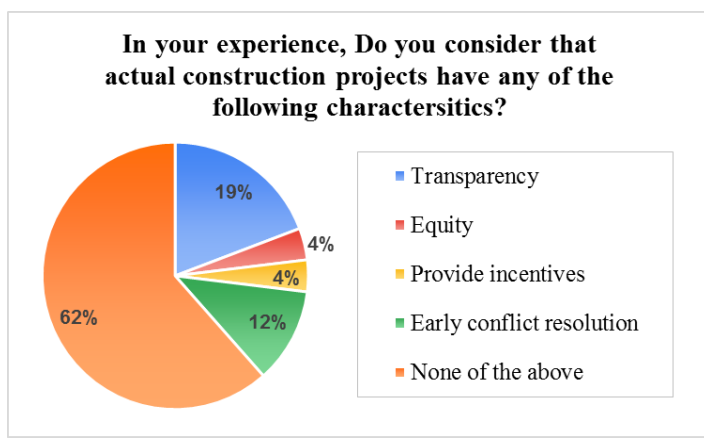

Fig 15: Circular Diagram about characteristics of traditional projects.

Table 8: Summary of responses about Benefits of using NEC Collaborative Management.

\begin{tabular}{|l|l|l|}
\hline \multicolumn{1}{|c|}{ FLEXIBILITY } & \multicolumn{1}{|c|}{ CLARITY } & \multicolumn{1}{c|}{ EFFICIENT MANAGEMENT } \\
\hline $\begin{array}{l}\text { Parties seek to support each other to achieve } \\
\text { common goals }\end{array}$ & Maintain objectives aligned with the project & $\begin{array}{l}\text { More than the use of NEC, the benefit is } \\
\text { achieved by the work philosophy. }\end{array}$ \\
\hline Improve perception of value & More benefit to the project. & Trust between the team and parties \\
\hline Appropriate distribution of risks & Transparency. & Collaboration. \\
\hline Benefits for all parties & Equity. & Adequate control of the project. \\
\hline $\begin{array}{l}\text { Assign responsibilities to the different } \\
\text { Stakeholders }\end{array}$ & Integration and understanding between Stakeholders. & $\begin{array}{l}\text { Promotes sensitive communication regarding } \\
\text { events that may cause negative impacts. }\end{array}$ \\
\hline \multicolumn{2}{|l|}{ Solve incompatibilities, errors, redesigns in a faster, less bureaucratic way and don't affect the project delivery time. } \\
\hline
\end{tabular}




\section{Conclusion}

The evaluation of Stakeholders in each project applies the vision of how they will be manage and interact with the project, this analysis allows to find interaction and communication deficiencies as well as apply a collaborative approach and search for benefits for all parties. Likewise, the application of matrixes proposed in this research will help to make an improvement in the management of stakeholders, as early as this methodology will applies, team of projects can interact with Stakeholders continuously and avoid errors due to redesigns, incompatibilities. Also, the solutions proposed will be faster and less bureaucratic with respect to traditional projects.

By applying the ICE sessions tool based on collaboration, communication and the correct performance of the team will generate an efficient and transparent management in all phases of the project with opportunities to hold sessions in which all doubts can be answered, disputes discussed or objectives defined based on the progress of the work. It's important to assign a person in charge who guarantee the correct execution of ICE sessions,

The use of expert judgment is a great tool that helped to validate the investigation, since as observed the main problems of NON-Stakeholders Management are: lack of teamwork, lack of communication and low interest. The Investigation, by focusing on these issues goes to the root cause of the problem. Therefore, applying a collaborative management of Stakeholders will reduce controversy times, rework, meet deadlines and improve the quality of final product. Also, it's important to note that the majority of traditional projects don't have appropriate characteristics to guarantee success of the project.

On the other hand, according to the answers about DAB application, can be concluded that this tool is important in a collaborative management because guarantees an environment of transparency and integration between the stakeholders. Likewise, the application of Dispute Adjudication Board (DAB) improves communication and times in dispute settlement. It's important to note that DAB is a pre-arbitration alternative and is used in a preventive and advisory manner in order to not reach an arbitration. For that matter, future contractual problems between the parties will be avoided, which would definitely generate a lower investment in cost and time.

\section{References}

[1] Gestión, "Estos son los tres distritos de Lima con mayor número de proyectos inmobiliarios," 2018. [Online]. Available: https://gestion.pe/tu-dinero/inmobiliarias/son-tres-distritos-lima-mayor-numero-proyectos-inmobiliarios-230675noticia/. [Accessed: 12-May-2020].

[2] Y. C. Li, W. H. Luk, and E. Cheng, "Hong Kong's first public sector NEC contract: Lessons learnt," in Proceedings of Institution of Civil Engineers: Management, Procurement and Law, 2016, vol. 169, no. 6, pp. 231-237.

[3] T. Davis and P. N. Thurlow, "Briefing: Good faith obligations in NEC contracts," Proceedings of Institution of Civil Engineers: Management, Procurement and Law, vol. 169, no. 4. pp. 145-146, 16-Feb-2016.

[4] H. E. A. Baharuddin, C. K. I. C. Ibrahim, S. B. Costello, and S. Wilkinson, "Managing stakeholders through alliances: A case study of a megaproject in New Zealand," Proc. Inst. Civ. Eng. Manag. Procure. Law, vol. 170, no. 4, pp. 151160, 2017.

[5] K. W. Mak, S. Hamill, and D. S. W. Kong, "Kennedy Town swimming pool, Hong Kong, China - An NEC journey," Proc. Inst. Civ. Eng. Civ. Eng., vol. 172, no. 1, pp. 23-28, Feb. 2019.

[6] LLV Consultores, LA JUNTA DE RESOLUCIÓN DE DISPUTAS, Mecanismo idóneo apra resolver las controversias de obra pública. Lima, 2020.

[7] BIM Corner, "Evertything about ICE meetings in VDC method," 2020. [Online]. Available: https://bimcorner.com/everything-about-ice-meetings-in-vdc-method-part-1/.

[8] G. Owen and B. Totterdill, "Implementing and enforcing a dispute board's decision," in Dispute boards: procedures and practice, 2016, pp. 129-138. 